\title{
Analysis of agonistic interactions between sows with different rank position during mixing
}

\author{
CATRIN BORBERG and STEFFEN HOY
}

Department of Animal Breeding and Genetics, Justus Liebig University Giessen, Germany

\begin{abstract}
Ninety-six sows in twelve groups of eight sows were continuously video-observed during 48 hours after weaning and mixing. The occurrence and the outcome of all agonistic interactions (Al) were recorded and data of wins and defeats were transformed into a $8 \times 8$ (winner-loser) matrix. Aggressor and receiver of the attacks and fights in the dyads have been determined and the rank index for each sow was calculated leading to the individual rank place RP (1 to 8) and to the classifying into high ranking (HRS: RP 1 to 4) and low ranking sows (LRS: RP 5 to 8). Based on a total number of $2414 \mathrm{Al}$ dominant sows with $\mathrm{RP}=1$ initiated $94.3 \%$ of the $\mathrm{Al}$ they were involved in and were the receiver in $5.7 \%$ of the Al. In contrast, every fourth Al was orientated towards the subdominant sow with $\mathrm{RP}=8$. The sows with $\mathrm{RP} 7$ or 8 were the receivers in nearly half of all $\mathrm{Al}(44.9 \%)$. Fights occurred more frequently between sows with a low rank place difference. More than $60 \%$ of the attacks and more than $40 \%$ of the fights were initiated from high ranking sows towards low ranking sows even though $28.6 \%$ was the estimated value for those dyads. In only $2 \%$ of the attacks and $18.8 \%$ of the fights LRS engaged HRS which means that HRS usually react with a counter-attack when being attacked by a LRS.
\end{abstract}

Keywords: sow, agonistic interaction, rank place, aggressor, receiver

\section{Zusammenfassung}

\section{Analyse der agonistischen Interaktionen zwischen Sauen verschiedener Rangpositionen bei der Gruppenbildung}

Insgesamt 96 Sauen aus 12 Gruppen zu je 8 Sauen wurden nach Absetzen und Neugruppierung über $48 \mathrm{~h}$ fortlaufend videoüberwacht. Das Auftreten und der Ausgang von allen agonistischen Interaktionen (Al) wurden registriert und die Siege und Niederlagen in eine $8 \times 8$-(Gewinner-Verlierer)-Matrix eingetragen. Der Initiator und die attackierte Sau der Angriffe und Kämpfe jeder Dyade wurden bestimmt. Es wurde der Rangindex für jede Sau berechnet und somit der individuelle Rangplatz RP (1 bis 8) ermittelt. Anschließend wurden die Sauen als ranghoch (HRS: RP 1 bis 4) und rangniedrig (LRS: RP 5 bis 8) klassifiziert. In 2414 ausgewerteten Al war die dominante Sau der jeweiligen Gruppe mit $\mathrm{RP}=1$ zu 94,3\% der Initiator der Al, in denen sie beteiligt war, und zu 5,7\% das attackierte Tier. Im Gegensatz dazu war die subdominante Sau $(\mathrm{RP}=8)$ von jeder vierten Al betroffen. Die Sauen mit RP 7 oder 8 waren die attackierten Tiere in nahezu der Hälfte aller Al (44,9\%). Kämpfe traten häufiger zwischen Sauen mit geringer 
Rangplatzdifferenz auf. Mehr als $60 \%$ der Angriffe und mehr als $40 \%$ der Kämpfe wurden von ranghohen Sauen initiiert und richteten sich gegen rangniedere Tiere, obwohl der Erwartungswert für diese Dyaden 28,6\% betrug. Nur 2\% der Angriffe aber 18,8\% der Kämpfe wurden von rangniederen Sauen begonnen gegen ranghohe Tiere gerichtet. Daraus ist abzuleiten, dass ranghohe Tiere üblicherweise mit einem Gegenangriff reagieren, wenn sie von einer rangniederen Gruppengefährtin attackiert werden.

Schlüsselwörter: Sau, agonistische Interaktion, Rangplatz, Angriff, Kampf

\section{Introduction}

Dominance relationships are a multi-dimensional phenomenon of all social living (farm) animals. It is necessary to characterize dominance at different levels of analysis (individual, dyad, group) as well as with well-defined and preferably standardized sociometric methods delivering a comprehensive "picture" of the social hierarchy of sows (LANGBEIN and PUPPE 2004, PUPPE et al. 2008). Fighting occurs between sows which are unfamiliar to each other leading to an established social ranking (MEESE and EWBANK 1973, VELARDE 2007). In newly formed groups of sows almost all individuals are involved in agonistic interactions with some of the sows carrying out most of the aggression and others being mainly the recipients (MOUNT and SEABROOK 1993, AREY and FRANKLIN 1995, MOORE et al. 1993, BARNETT et al. 1992, O'CONNELL et al. 2003, D'EATH 2004). Investigations of D'EATH (2004) showed differences between individuals concerning aggressive behaviour of pigs during a resident-intruder test. Sows with low social status get injured at more body regions caused by agonistic interactions and the injuries are stronger (O'CONNELL et al. 2003). The agonistic interactions which occur due to mixing sows result in physiological stress responses (AREY and EDWARDS 1998). Sows with low rank position had a higher B-endorphine level leading to the interpretation that sows are able to adapt to the given conditions by activating the endogeneous opioid system (ZANELLA et al. 1998).

As of 2013, all sows and gilts are required to be kept in groups during a period starting four weeks after the service until one week before the expected time of farrowing referring to EC directive 2001/88/EC. To prevent detrimental effects on reproductive parameters such as return to heat and a smaller number of live born piglets per litter a better understanding of the dominance relationships between the sows during mixing is necessary.

So, the aim of the present paper is to analyse the agonistic interactions between high and low ranking sows during mixing.

\section{Material and methods}

\section{Animals}

Ninety-six sows (German Landrace, Edelschwein and hybrids from those breeds) in twelve groups were included in the investigation. The sows were kept in the research station of the Department of Animal Breeding and Genetics of the Justus Liebig University Giessen. After the weaning of the piglets groups of eight mostly unfamiliar sows (no primiparous sows or gilts) were placed in a stimulation pen (BAUER and HOY 2002). The weaning always occurred on Thursday morning. Ear marks and tags and especially a large black 
number on the back allowed individual identification of the animals. The research station performs a three-weekly cycle with an average nursing period of 26 days. That means every third Thursday a group of eight sows was put into the stimulation pen for $48 \mathrm{~h}$.

\section{Housing, feeding and management}

The stimulation pen measured $27.2 \mathrm{~m}^{2}$ ( $3.4 \mathrm{~m}^{2}$ for each sow). The pen had a concrete floor with straw as litter material. The sows were fed with a standard ration of cereal based feed ad libitum from a tube feeder. Water was available ad libitum through two nipple drinkers. The stimulation pen was installed in a non-isolated building with natural ventilation. In addition to natural light, an artificial light-programme was carried out from 6 to 22 o'clock. On Saturday morning all eight sows were brought into the service centre containing individual stalls. The sows were artificially inseminated between Tuesday and Thursday. During the $48 \mathrm{~h}$ housing period in the stimulation pen temperature and humidity were recorded.

\section{Behavioural observation}

Behavioural observation took place during 48 consecutive hours after introduction (after weaning) from 9 to 9 o'clock with the infrared video technique described by Hoy (1998). The video recording equipment consisted of an IR camera (WV-BP 500 with aspheric lens WV-L 262/ZE), a time lapse video recorder AG-TL 300, an IR lamp WF-I/LED 40/230 and a monitor WV-BM 900. The occurrence and the outcome of all agonistic interactions (Al) were analysed using a video recorder with jog/shuttle function and a large TV monitor. The behavioural patterns used are defined in Table 1.

Table 1

Definition of the ethological patterns used

Definition der verwendeten ethologischen Parameter

\begin{tabular}{|c|c|}
\hline Term & Definition \\
\hline Agonistic interaction (Al) & $\begin{aligned} \text { Biting of another sow; conditions are: } & \\
- & \text { physical contact between the sows } \\
- & \text { reaction of the receiver (counter-attack or flight) } \\
- & \text { lateral fight }\end{aligned}$ \\
\hline Attack & Unilateral action: the attacked sow doesn't bite back \\
\hline Fight & Bilateral action: the attacked sow bites back \\
\hline Aggressor/Receiver & Aggressor: attacking sow; Receiver: sow being attacked \\
\hline Winner/Loser & Winner wins the $\mathrm{Al}$, Loser loses the $\mathrm{Al}$ \\
\hline Rank index (RI) & $\begin{array}{l}R I=\frac{\left(S \cdot P_{S}\right)-\left(N \cdot P_{N}\right)}{(S+N) \cdot(n-1)} \quad-1 \geq R I \leq 1 \\
\text { where is } S \text { the number of wins, } P_{S} \text { the number of partners against sow has won, } \\
N \text { the number of defeats, } P_{N} \text { the number of partners, against sow has lost and } n \\
\text { the group size. }\end{array}$ \\
\hline Rank place (RP) & $\begin{array}{l}\text { The } \mathrm{RI} \text { in each group of eight sows were categorized with } \mathrm{RP}=1 \text { for the highest } \\
\text { and } \mathrm{RP}=8 \text { for the lowest } \mathrm{RI} \text {. }\end{array}$ \\
\hline High ranking sows (HRS) & Sows with $\mathrm{RP}=1$ to 4 \\
\hline Low ranking sows (LRS) & Sows with $\mathrm{RP}=5$ to 8 \\
\hline
\end{tabular}


Data on wins and defeats were transformed into a winner-loser matrix with the rows labelled as wins and the columns labelled as defeats. Based on these matrices the total number of $\mathrm{Al}$ in $48 \mathrm{~h}$ per sow was determined. The rank index (RI) for each sow was calculated using the number of wins and defeats, the number of group-partners the sow had defeated or had lost to and the group size (following LANGBEIN and PUPPE 2004, HOY et al. 2005, PUPPE et al. 2008). The rank index can vary from -1 to +1 . The sow with the highest $\mathrm{Rl}$ in each group was defined as rank place or rank position (RP)=1, the sow with the lowest $\mathrm{Rl}$ as $\mathrm{RP}=8$. The sows with $\mathrm{RP}=1$ to 4 were categorized as high ranking sows (HRS), those with $R P=5$ to 8 as low ranking sows (LRS).

The statistical analysis was done using the SPSS programme 15.0 for Windows. The Student-Newman-Keuls test was used to compare means. The comparison between the observed and the expected frequencies of $\mathrm{Al}$, attacks or fights between sows with different rank places ( 1 to 8 ) or rank categories (HRS, LRS) was carried out with the Chi-Square test in contingency tables. The level of significance was set at $P<0.05$ or $P<0.01$.

\section{Results}

A total number of $2414 \mathrm{Al}$ took place in the 12 groups with 8 sows each. We observed 2105 attacks ( $87.2 \%$ of all $\mathrm{Al}$ ) and 309 fights ( $12.8 \%$ of all Al) between the group-mates during mixing ( $48 \mathrm{~h}$ in each group). The Al was started by the higher ranking sow of the dyad in $90.3 \%$ of all cases. Regarding the attacks, the sow with the higher rank position was the aggressor in $94.8 \%$ of all attacks. Concerning the fights, the HRS was the initiator in $59.9 \%$ of all fights.

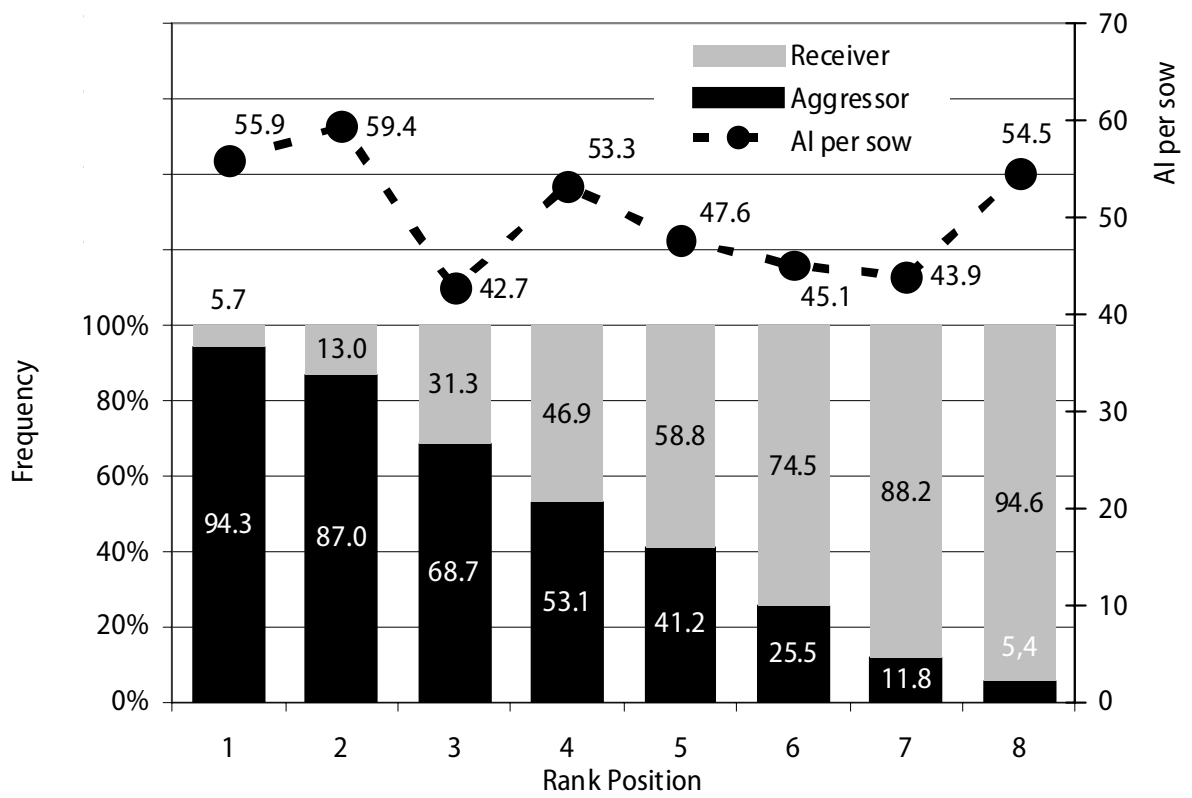

Figure 1

Relationships between rank position, the frequency of Al (per sow and $48 \mathrm{~h}$ ) and the frequency to act as aggressor or receiver

Zusammenhang zwischen Rangposition, Häufigkeit von Al (pro Sau und 48 h) und der Häufigkeit, Angreifer zu sein oder attackiert zu werden 
The sows with the rank places 1, 2 and 8 were involved in most of the Al (between 54.5 and $59.4 \mathrm{Al}$ per sow in $48 \mathrm{~h}$ ) (Figure 1). The frequency to initiate an agonistic interaction as aggressor was decreased with decreasing social status. The sow with the highest RP $(=1)$ was the aggressor in $94.3 \%$ and the receiver in $5.7 \%$ of all Al she has been involved in. Vice versa, the LRS with the lowest rank position 8 was the aggressor in $5.4 \%$ and the receiver in $94.6 \%$ of all $\mathrm{Al}$ (Figure 1).

Based on the total number of Al should be noted that the sow with the lowest rank place was attacked in every fourth AI (25.6\%). The sows with RP 7 or 8 were the receivers in nearly the half of all $\mathrm{Al}(44.9 \%)$. In the opposite, the sows with the two highest rank positions 1 or 2 were the aggressors in more than $50 \%$ of all agonistic interactions (Figure 2).

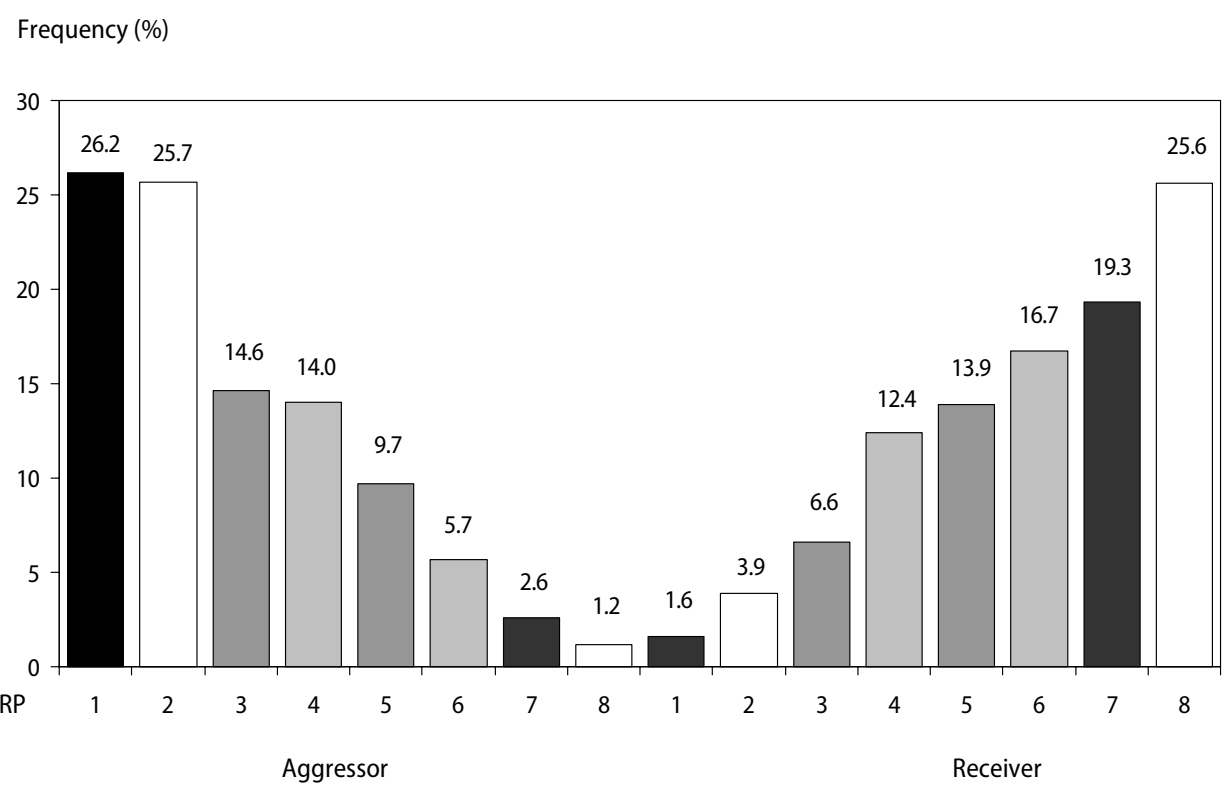

Figure 2

Frequency of acting as aggressor or receiver depending on different rank positions - based on the total number of $\mathrm{Al}(\mathrm{n}=2$ 414)

Häufigkeit des Agierens als angreifende oder angegriffene Sau in Abhängigkeit von der Rangposition - auf der Grundlage aller Al ( $n=2414)$

Analysing the $\mathrm{Al}$ regarding the rank place differences $\triangle \mathrm{RP}$ between the group-mates, it can be shown that a large frequency of agonistic interactions (in absolute numbers) took place between sows with adjoining rank places (Table 2). Twenty-eight dyads exist in a group of eight individuals. According to that each dyad (e.g. sow 1 vs. sow 4) has an expected percentage of occurrence of $3.57 \%$. Dyads with a $\triangle \mathrm{RP}$ of one rank place have the highest frequency (seven times: $1: 2,2: 3,3: 4,4: 5,5: 6,6: 7$ and $7: 8$ ) followed by a $\Delta R P$ of two (six times) and so on. There is only one dyad in a group of 8 sows with a difference in the rank places of seven (rank place 1 vs. rank place 8). Therefore the expected value has to include the number of possible dyads with the same $\triangle R P$ and is calculated by the number of dyads multiplied with the expected frequency for each dyad 
(3.57\%). So, a rank place difference of one with seven dyads has an expected frequency of $\mathrm{Al}$ of $25.0 \%$, whereas a RP difference of seven has an expected frequency of $3.57 \%$ (Table 2).

Table 2

Observed and expected frequencies of Al between dyads with various rank place differences ( $\triangle \mathrm{RP})$ Beobachtete und erwartete Häufigkeiten von Al in Dyaden mit verschiedenen Rangplatz-Differenzen ( $\triangle R P)$

\begin{tabular}{lcccccccr}
\hline$\Delta \mathrm{RP}$ & 1 & 2 & 3 & 4 & 5 & 6 & 7 & Total \\
\hline Number of Al & 452 & 452 & 431 & 400 & 300 & 225 & 154 & 2414 \\
Frequency of Al, \% & 18.7 & 18.7 & 17.9 & 16.6 & 12.4 & 9.3 & 6.4 & 100 \\
Number of dyads & 7 & 6 & 5 & 4 & 3 & 2 & 1 & 28 \\
Expected frequency of Al, \% & 25.0 & 21.4 & 17.9 & 14.3 & 10.7 & 7.1 & 3.57 & 100 \\
\hline
\end{tabular}

Comparing the observed frequencies of Al of the various rank place differences with the expected values, it can be shown that Al occurred more often the more the distance in rank places of the sows increased (Figure 3). The difference between the observed and the expected values is significant $(P<0.01)$. Between sows with a RP difference of 1 or 2 , far less than anticipated Al took place.

The same tendencies are obtained when attacks and fights are calculated separately. Sows with adjoining rank places $(\triangle \mathrm{RP}=1$ or 2$)$ carry out less attacks against each other (compared with the expected frequencies) than sows with a large difference in their RP.

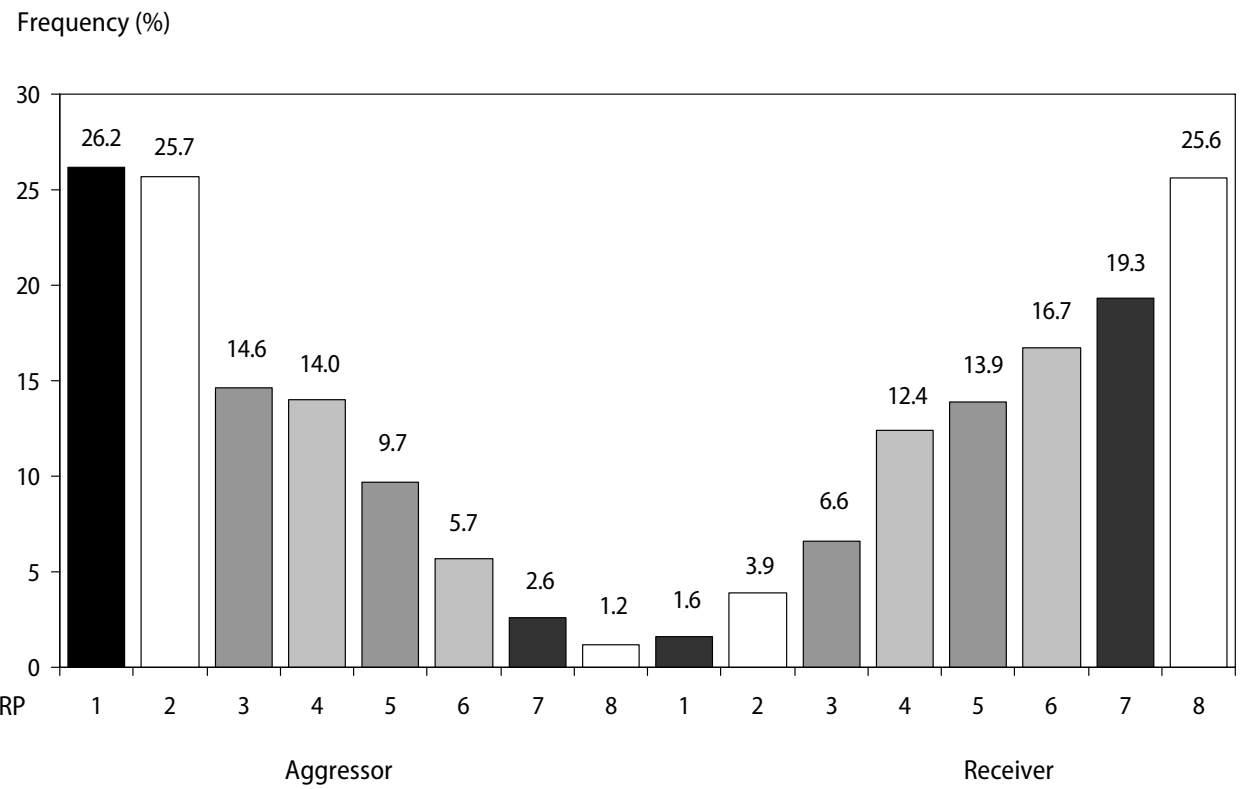

Figure 3

Comparison of observed and expected frequencies of $\mathrm{Al}$ in dependence on difference of rank places $\Delta \mathrm{RP}$ Vergleich der beobachteten und erwarteten Häufigkeiten von Al in Abhängigkeit von der Differenz in den Rangplätzen $\triangle R P$ 
Classifying the sows with RP 1 to 4 as high ranking sows (HRS) and the group-mates with RP 5 to 8 as low ranking sows (LRS), it can be demonstrated that $80.5 \%$ of all Al were initiated by HRS (table 3 ). The receiver was a LRS in $75.5 \%$ of all cases. A total number of $20.3 \%$ of the Al were carried out between high ranking sows and $15.3 \%$ of the Al took place between LRS. Most of the AI (60.2\%) which had taken place between HRS and LRS were initiated by the HRS and only $4.2 \%$ by the LRS. Because of the different probability of the occurrence of HRS : HRS- (e.g. $1: 2,1: 3,1: 4,2: 3,2: 4,3: 4)$ or HRS:LRS- $(1: 5,1: 6$, $1: 7,1: 8,2: 5,2: 6,2: 7,2: 8$ and so on) relationships (and similar for LRS : LRS or LRS : HRS) the expected frequencies have to be taken into account (Table 3). Analysing attacks and fights separately, it can be shown that $63.2 \%$ of the attacks were carried out by high ranking against low ranking sows but only $2.0 \%$ in the opposite direction (Figure 4). In contrast, fights were initiated by HRS against LRS only in $40.1 \%$ of all fights. A fight occurred in $18.8 \%$ of all cases if the aggressor was a LRS and the receiver was a HRS.

Table 3

Observed and expected frequencies of Al between dyads with various rank category

Beobachtete und erwartete Häufigkeiten von Al in Dyaden mit verschiedenen Rang-Kategorien

\begin{tabular}{lccccc}
\hline & HRS : HRS & HRS : LRS & LRS : HRS & LRS : LRS & Total \\
\hline Number of Al & 490 & 1454 & 101 & 369 & 2414 \\
Frequency of Al, \% & 20.3 & 60.2 & 4.2 & 15.3 & 100 \\
Number of possibilities & 12 & 16 & 16 & 12 & $56^{*}$ \\
Expected frequency of Al, \% & 21.43 & 28.57 & 28.57 & 21.43 & 100 \\
\hline
\end{tabular}

HRS high ranking sows, LRS low ranking sows, * twice the number because of the bidirectionality of the dyads (2.28)

Frequency (\%)

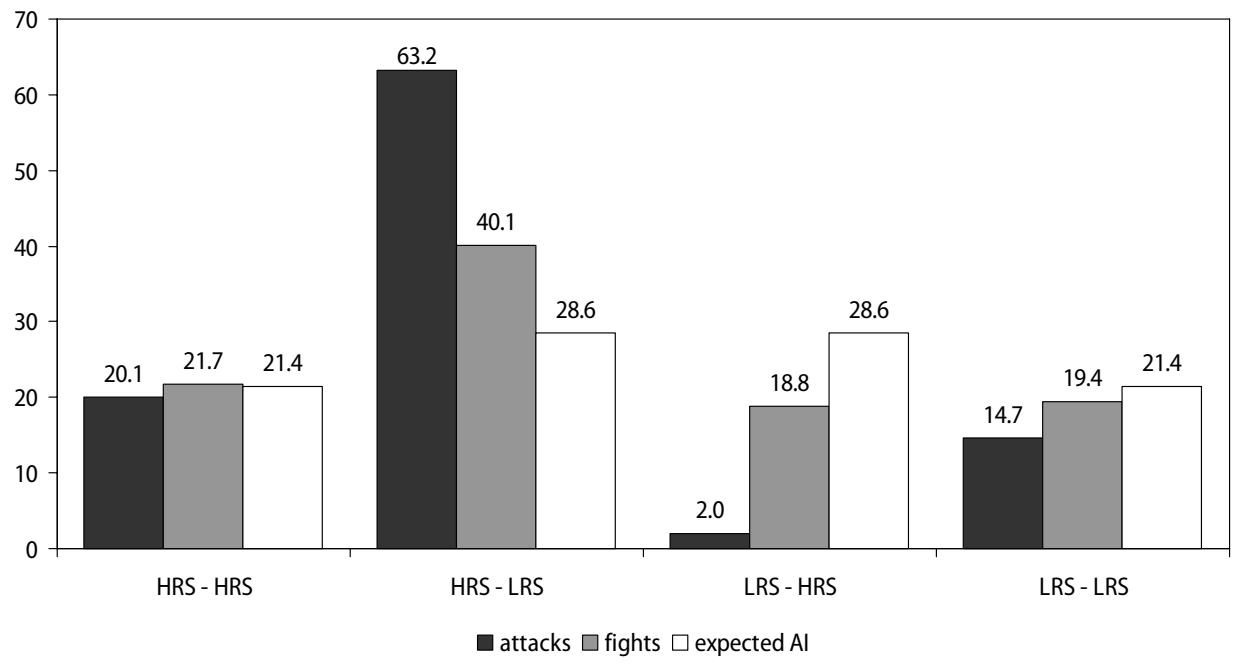

differences between observed and expected frequencies (attacks, fights) $P<0.01$

Figure 4

Comparison of observed and expected frequencies of attacks and fights in dependence on rank category (HRS, LRS)

Vergleich der beobachteten und erwarteten Häufigkeiten von Angriffen und Kämpfen in Abhängigkeit von der Rang-Kategorie (HRS, LRS) 


\section{Discussion}

The problem of severe fightings for rank position after mixing of unfamiliar sows is relevant both from the viewpoint of animal welfare as well as for economical reasons (MARCHANT et al. 1995, O'CONNELL et al. 2003, HOY et al. 2005). Many studies were focussed on different possibilities to reduce the frequency and the intensity of agonistic interactions between newly mixed sows. The aim of the present study was to analyse the social relationships (attacks, fights) in groups of sows after mixing, taking into account the social status of the group-mates. No gilts and no primiparous sows were included in the investigations. A certain level of familiarity between the sows was given due to a herd size of 90 sows at the research station. It is known that sows renew their dominance relationships after a longer period of separation (MCGLONE 1986, AREY and FRANKLIN 1995, PUPPE et al. 2008). However, the sows obviously do not seem to be able to remember their group-mates to the same extent after 28 days than they could after only 7 days of separation (HOY and BAUER 2005). BAUER (2005) demonstrated that two sows of a dyad meeting again after a five months period of separation nearly had the same probability to win or to lose the fights for rank position. The investigation showed that with decreasing social status the sows acted less as aggressor but rather were a receiver. More than $50 \%$ of the Al were initiated by the sows with rank positions 1 or 2 . Dominant sows with the rank position 1 initiated more than $90 \%$ of the Al they were involved in. Nearly half of the Al were addressed against the two low ranking sows with RP 7 or 8 . Based on the expected frequencies ( $3.57 \%$ per dyad), it has to be underlined that less attacks occurred between sows with adjoining rank positions compared with sows having a large difference in their rank places. Categorizing the sows into rank classes (HRS vs. LRS), it can be shown that both the number of attacks as well as the fights occurring in-between the same rank category correspond with the expected frequency. Between different rank categories HRS attacked LRS in $63.2 \%$ of all Al and initiated a fight against a LRS in $40.1 \%$ of all cases. In contrast to that LRS attacked HRS only in $2 \%$ of all Al but initiated a fight in $18.8 \%$ of all fights. That means that a HRS answers an attack of a LRS with a counter-attack leading to a fight whereas vice versa LRS tend to take flight after having been attacked by a HRS. AREY (1999) noted that in a dynamic group of pregnant sows only $4.2 \%$ of the Al were initiated by the newly introduced sows. In the present investigation, the LRS, especially those with RP 7 or 8 , were attacked disproportionately frequent. KAY et al. (1999) measured the flight distance of low ranking sows with more than $13 \mathrm{~m}$ and the attack distance of high ranking sows with less than $6.8 \mathrm{~m}$. The longest possible distance (diagonal) in the stimulation pen of this experiment was $8.0 \mathrm{~m}$. Obviously, this distance was too short for the LRS to escape. So, it is to be recommended, to enlarge the pen for mixing unfamiliar sows to reduce the frequency of aggressive interactions (MENDL et al. 1992).

With the present investigations, it was possible to describe the social interactions between the group-mates after mixing more precisely than before and at an individual level. Fighting to establish a social rank order belongs to the normal species-specific behaviour of sows and cannot be prevented. But it is demanded to reduce physiological stress with possible effects on reproductive performance (HOY et al. 2008, BORBERG 2008) 
by management. With an increasing number of acquainted sows in a group the frequency of Al on group level can be reduced (BORBERG 2008).

\section{Acknowledgement}

The project was financed by the Deutsche Forschungsgemeinschaft Bonn.

\section{References}

Arey DS (1999) Time course for the formation and disruption of social organisation in group-housed sows. Appl Anim Behav Sci 62, 199-207

Arey DS, Edwards SA (1998) Factors influencing aggression between sows after mixing and the consequences for welfare and production. Livest Prod Sci 56, 61-70

Arey DS, Franklin MF (1995) Effects of straw and unfamiliarity on fighting between newly mixed growing pigs. Appl Amin Behav Sci 45, 23-30

Barnett JL, Hemsworth PH, Cronin GM, Newman EA, McCallum TH, Chilton D (1992) Effects of pen size, partial stalls and method of feeding on welfare-related behavioural and physiological responses of group-housed pigs. Appl Anim Behav Sci 34, 207-20

Bauer J (2005) Investigations on mixing sows under the aspects of behaviour, health and performance. PhD Thesis Univ Giessen, Germany [in German]

Bauer J, Hoy St (2002) Frequency of fighting for rank order during first and repeated mixing of sows. Proc Aktuelle Arbeiten zur artgemäßen Tierhaltung. KTBL-Schrift 418, 181-7 [in German]

Borberg AC (2008) Analysis of the agonistic interactions during grouping of sows with or without a boar. PhD Thesis Univ Giessen, Germany [in German]

D'Eath RB (2004) Consistency of aggressive temperament in domestic pigs: The effects of social experience and social disruption. Aggress Behav 30, 435-48

Hoy St (1998) Use of infrared videotechnique in the applied farm animal ethology. Tierärztl Umschau 53, 554-9 [in German]

Hoy St, Bauer J (2005) Dominance relationships between sows dependent on the time interval between separation and reunion. Appl Anim Behav Sci 90, 21-30

Hoy St, Bauer J, Weirich C (2005) Sociometric investigations during grouping of sows. KTBL-Schrift 437, 173-85 [in German]

Hoy St, Bauer J, Borberg AC, Weirich C (2008) Investigation on occupational behaviour of female and castrated male fattening pigs. Arch Tierz 51, 458-66 [in German]

Kay RM, Burfoot A, Spoolder HAM, Docking CM (1999) The effect of flight distance on aggression and skin damage of newly weaned sows at mixing. Ann Meeting Brit Soc Anim Sci, Scarborough Brit Anim Sci

Langbein J, Puppe B (2004) Analysing dominance relationships by sociometric methods - a plea for a more standardised and precise approach in farm animals. Appl Anim Behav Sci 87, 293-315

Marchant JN, Mendl MT, Rudd AR, Broom DM (1995) The effect of agonistic interactions in the heart rate of group-housed sows. Appl Anim Behav Sci 46, 49-56

McGlone JJ (1986) Influence of resources on pig aggression and dominance. Behav Proc 12, 135-44

Meese GB, Ewbank R (1973) The establishment and nature of the dominance hierarchy in the domesticated pig. Anim Behav 21, 326-34

Mendl M, Zanella AJ, Broom DM (1992) Physiological and reproductive correlates of behavioural strategies in female domestic pigs. Anim Behav 44, 1107-21

Moore AS, Gonyou HW, Ghent AW (1993) Integration of newly introduced and resident sows following grouping. Appl Anim Behav Sci 38, 257-67

Mount NC, Seabrook MF (1993) A study of aggression when group housed sows are mixed. Appl Anim Behav Sci 36, 377-83

O'Connell NE, Beattie VE, Moss BW (2003) Influence of social status on the welfare of sows in static and dynamic groups. Anim Welf 12, 239-49

Puppe B, Langbein J, Bauer J, Hoy St (2008) A comparative view on social hierarchy formation at different stages of pig production using sociometric measures. Livest Sci 113, 155-62 
Velarde A (2007) Agonistic behaviour. In: Velarde A, Geers R (eds) On farming monitoring of pig welfare. Wageningen Academic Publishers, Wageningen, The Netherlands

Zanella AJ, Brunner P, Unshelm J, Mendl MT, Broom DM (1998) The relationship between housing and social rank on cortisol, ß-endorphin and dynorphin (1-13) secretion in sows. Appl Anim Behav Sci 59, $1-10$

Received 26 June 2009, accepted 2 October 2009.

Corresponding author:

Prof. Dr. STEFFEN HOY

email: steffen.hoy@agrar.uni-giessen.de

Department of Animal Breeding and Genetics, Justus Liebig University Giessen, Bismarckstrasse 16, 35390 Giessen, Germany 